\title{
Margaret McCartney: We need another vote
}

\author{
Margaret McCartney general practitioner
}

Glasgow

You're going on holiday to a place called Utopia, which is lovely, or so they say. Your case is packed, and you have your passport and visa.

Then come murmurings about the weather. What do the meteorologists say? Well, we've had enough of experts. You're told that lots of doctors and nurses are leaving Utopia. People from the business world are starting to worry about the effects of trade deals on the economy. A country very nearby, whose recent history of terrorism has been largely quelled, starts to explain how Utopia might destabilise its peace. You read claims that the Utopia advertising campaign was influenced by online hackers. So, what do you do? Well, you could decide not to holiday in Utopia. You're allowed to stay where you are, without penalty.

Autonomous adults make decisions others may judge as unwise, or illogical, or frankly ridiculous. In a medical model this is ethically correct—but, ethically, it also requires properly informed choice. Why should the validity of information be different in a political landscape? The effects of Brexit are likely to have major effects on the NHS and to be no less important than many decisions we take about our health.

Furthermore, in a decision making situation, when new information comes to light-whether it's an economic analysis or revelations about hacking-re-evaluation is necessary. This should be our right. The country should not be held permanently to decisions made on incomplete or wrong information.

Much evidence indicates that the NHS will become less safe after Brexit. Some $7.7 \%$ of current NHS doctors are from other countries in the European Economic Area, nearly half (45\%) of whom are considering quitting the UK. And of these, 39\% have already made plans to leave. ${ }^{1}$ Over $10000 \mathrm{EU}$ staff had already left the NHS in the 12 months to June 2017, an increase of $22 \%$ on the previous year. ${ }^{2}$ The vacancies in the NHS are serious, harmful, and rising: up 10\% from 2016 to 2017 . $^{3}$
The country should not be held permanently to decisions made on incomplete or wrong information

The medical research community is a net beneficiary of EU research grants and has enjoyed EU collaboration for better powered trials. ${ }^{4} \mathrm{~A}$ faltering post-Brexit economy will mean more cuts to the NHS. Leaving the EU drug licensing system may create delays similar to those experienced in Switzerland and Canada, which are typically months behind the EU in approving drugs. The EU has been a force in helping the UK keep up with its neighbours on hitting targets for reducing air pollution. ${ }^{5}$ Without aspiring to do better we may just fall behind, getting dirtier and unhealthier.

We should have another vote, this time armed with evidence based information on what it is that we are voting for. We need informed choice, and the best informed consent has a cooling-off period.

Competing interests: See www.bmj.com/about-bmj/freelancecontributors/margaret-mccartney.

Provenance and peer review: Commissioned; not externally peer reviewed.

Follow Margaret on Twitter, @mgtmccartney

BMA. EU survey. 30 Nov 2017. https://www.bma.org.uk/collective-voice/influence/europe/ brexit/eu-survey.

2 NHS Digital. HCHS staff in NHS trusts and CCGs. Jun 2017. http://digital.nhs.uk/media/ 32470/HCHS-staff-in-NHS-Trusts-and-CCGs-Jun-17/xls/HCHS_staff_in_NHS_Trusts_ and_CCGs_Final_Jun 17.

3 Forster K. NHS faces "unprecedented crisis" as vacancies rise. 25 Jul 2017. www. independent.co.uk/news/health/nhs-staff-vacancies-rise-10-per-cent-2017-86000-nursesmidwives-doctors-recruitment-crisis-brexit-a7858961.html.

4 Royal College of Physicians. Brexit: what does it mean for medical research? $12 \mathrm{Apr}$ 2017. https://www.rcplondon.ac.uk/projects/outputs/brexit-what-does-it-mean-medicalresearch.

5 FahyNHerveyTGreerS. How will Brexit affect health and health services in the UK? Evaluating three possible scenarios. Lancet2017;390:2110-8. doi:10.1016/S0140-6736(17)31926-828965715

Published by the BMJ Publishing Group Limited. For permission to use (where not already granted under a licence) please go to http://group.bmj.com/group/rights-licensing/ permissions 